\title{
A comparison of the effects of Lotus and white clover on some nutrient cycling factors
}

\author{
J.R. CRUSH and R.G. KEOGH ${ }^{1}$ \\ AgResearch, Ruakura Research Centre, Private Bag 3123, Hamilton \\ ${ }^{1}$ AgResearch, Grasslands Research Centre, Private Bag 11008, Palmerston North
}

\begin{abstract}
In a laboratory test, nitrification rates were lower in soil incubated with dried Lotus herbage than in the same soil incubated with white clover herbage. Nitrification rates in soil amended with dried Lotus herbage were higher in soil that had grown Lotus for the previous three years, than in soil that had only one year in Lotus. This was interpreted as evidence for progressive selection for soil microorganisms that can readily decompose Lotus. This conclusion was supported by observation of rapid availability of nitrogen from Lotus herbage and dung when they were added to a hill soil that had grown Lotus for at least 6 years. Field sampling showed higher earthworm numbers under white clover pasture, than under Lotus pasture or ryegrass pasture, which had the lowest number. Dung from animals grazing Lotus pasture was incorporated more rapidly by earthworms than dung from white clover or ryegrass pastures, in laboratory and field experiments. This demonstrated preferences by earthworms among dungs derived from different pasture species. Further work is required to determine the effects on nutrient cycling processes of the different dung incorporation rates that were measured.
\end{abstract}

Keywords: condensed tannins, earthworms, Lotus, nitrogen, nutrient cycling, soil micro-organisms, white clover

\section{Introduction}

White clover-based pastures under intensive grazing are characterised by rapid movement of large volumes of nutrients through the soil-plant-animal system. When elements such as nitrogen $(\mathrm{N})$ cross from agricultural to non-agricultural ecosystems, significant damage can be caused to groundwater and surface water quality (Boothroyd et al. 1999). Other vegetation systems that are dominated by tannin-containing plants appear to conserve nitrogen $(\mathrm{N})$. Polyphenols in herbage inhibit nitrification of plant $\mathrm{N}$ in the soil (Vallis \& Jones 1973; Palm \& Sanchez 1991), probably by inhibiting oxidation of ammonium-N (Kholdebarin \& Oertli 1994).
In this paper we compare some effects of the tannincontaining plants Lotus (Lotus pedunculatus) and birdsfoot trefoil (L. corniculatus), and white clover (tannin-free) on nitrification, earthworm densities, and dung incorporation rates.

\section{Methods}

\section{Tannins and nitrification of plant nitrogen}

1. Lismore silt loam soil was collected from 1- and 3year-old Lotus crops and adjacent areas under white clover/ryegrass pasture. The samples were sieved, thoroughly mixed and $300 \mathrm{~g}$ wet weight samples were weighed out. Treatments applied separately to each soil were: (1) $200 \mathrm{mg} \mathrm{N}$ as oven-dried, finely ground white clover herbage; (2) $200 \mathrm{mg} \mathrm{N}$ as ovendried, finely ground Lotus herbage; (3) Control no amendment. The gravimetric water content of the treated soils was $28-32 \%$. Field water capacity for Lismore soil is estimated to be $36 \%$. Subsamples $(10 \mathrm{~g})$ of each treated soil were weighed into thin polythene bags (Eno 1960), sealed tightly to prevent moisture loss, and put into an incubator at $20^{\circ} \mathrm{C}$ within 48 hours of removal from the field. Extractable-nitrate concentrations were measured on 5 replicates of each treatment at weekly intervals for 6 weeks.

2. A yellow-brown loam soil from a low fertility hill pasture that had contained Lotus for at least 6 years (Lambert et al. 1986) was sieved and air-dried. Subsamples of soil $(10 \mathrm{~g})$, were mixed with sand (30 g), $200 \mathrm{mg}$ of dried ground herbage or dung, 6 $\mathrm{ml}$ of water and incubated at $25^{\circ} \mathrm{C}$ for 18 days. Treatments were: Control (no amendment), ryegrass herbage, ryegrass + Lotus herbage, dung derived from the ryegrass or dung derived from the ryegrass + Lotus. There were 4 replicates of each treatment. At the end of the incubation, mineral $\mathrm{N}$ was extracted with $\mathrm{KCl}$ and measured colorimetrically.

3. Grasslands Tama ryegrass was grown in pots of the same hill soil amended with nothing, ryegrass dung, or the ryegrass + Lotus dung (20 mg/g dry soil). There were 15 replicates and they were all given minus-N nutrient solution (Middleton \& Toxopeus 1973), weekly. DM cuts were taken after 27 and 48 days' growth. 


\section{Earthworm densities}

Earthworm densities under grazed monocultures that had been established for more than 2 years on a Kairanga silt loam, were determined from pasture cores $(255 \mathrm{~mm}$ diam.) using a hand-sorting technique. Three cores were taken from each of Grasslands Huia white clover, Nui perennial ryegrass, and birdsfoot trefoil (cv. Grasslands Goldie) pastures in late autumn (May). Earthworms recovered were identified to species, and number and biomass recorded for each species. A similar set of samples was also taken in December from pastures on a Tokomaru silt loam, but with a Lotus (cv. Grasslands Maku) sward in place of Goldie.

\section{Rate of dung disappearance}

1. Mixed populations of earthworms (Aporrectodea caliginosa and Lumbricus rubellus) were established in containers of coarse sand. Dung, derived from sheep grazing white clover, perennial ryegrass, or Lotus herbage was applied to the surface of the sand. There were 3 replicates of each treatment. The rates of removal of dung from the surface by earthworms were estimated from differences in the weight of dung remaining on the surface of containers with and without earthworms. Dung residues remaining on the surface were monitored for 4 weeks on each occasion and the results expressed as \% dung removed from the surface. Earthworm biomass was also recorded at the start and end of each of two experiments.

2. Dung was collected and deep-frozen each day from housed animals fed ryegrass-white clover herbage from plots with, or without $\mathrm{N}$ fertiliser, or ryegrass/ Lotus herbage. The experimental site was ryegrass/ Paspalum/white clover pasture on a Te Kowhai soil at Ruakura. The dung was thawed, mixed, analysed for $\mathrm{N}$ content, and $5 \mathrm{~kg}$ of moist dung was applied to $0.1 \mathrm{~m}^{2}$ plots in early summer. There were 4 replicates of each treatment, and the site was spray irrigated to maintain soil moisture above $50 \%$ field capacity. After 11 weeks without grazing, the dung remaining on the soil surface was dried, weighed and analysed for $\mathrm{N}$ content.

\section{Results}

\section{Nitrification of plant nitrogen}

Soils amended with ground Lotus herbage contained less nitrate nitrogen after 42 days' incubation than the same soil amended with clover herbage (Figure 1). After the addition of ground Lotus herbage, nitrate accumulated at a similar rate in both the 1- and 3-year white clover soils (Figure 1B, 1D), and the 1-year-old Lotus crop soil (Figure1A). In the soil from a 3-year- old Lotus crop (Figure 1C), the nitrification rate after addition of Lotus herbage was significantly $(P<0.01)$ higher than was recorded for the other Lotus herbage treatments.

In the second incubation experiment, mineral $\mathrm{N}$ levels after 18 days did not differ significantly between the control soil and soil mixed with ryegrass herbage (Table 1). Mineral $\mathrm{N}$ in the other treatments was in the order Lotus herbage $>$ ryegrass $<$ ryegrass dung $<$ Lotus/ ryegrass dung. All these differences were significant $(P<0.05)$.

In the pot experiment, Tama ryegrass total DM yields were twice as high for soil mixed with dung than in the control pots (Table 1). There was a small but significant $(P<0.01)$ increase in DM in the grass + Lotus dung treatment, compared with the grass dung pots.

Table 1 Mineral $\mathrm{N}$ accumulated ( $\mu \mathrm{g} \mathrm{N} / \mathrm{g}$ dry soil) over 18 days' incubation of a hill soil amended with ground ryegrass or Lotus herbage, or dung derived from these forages, and DM yield of Tama ryegrass grown in pots of soil mixed with the dungs.

\begin{tabular}{lrcccc}
\hline & Control & ryegrass & $\begin{array}{c}\text { ryegrass } \\
\text { + Lotus }\end{array}$ & $\begin{array}{c}\text { ryegrass } \\
\text { dung }\end{array}$ & $\begin{array}{c}\text { ryegrass+Lotus } \\
\text { dung }\end{array}$ \\
\hline Mineral N & 105 & 118 & 195 & 275 & 352 \\
mg DM yield & 1075 & & & 1919 & 2112 \\
\hline
\end{tabular}

\section{Earthworm densities}

For both sets of samples, earthworm numbers were substantially higher under legume than under ryegrass pastures (Table 2), and were also higher under white clover than under Lotus. A. caliginosa was numerically the dominant species in both white clover and Lotus pastures, making up $70 \%$ of the individual worms counted (Table 3). However, L. rubellus formed more of the biomass, especially in white clover pasture $(64 \%$ of total earthworm weight) compared with in Lotus pasture (54\% of total weight).

Table 2 Earthworm biomass $\left(\mathrm{g} / \mathrm{m}^{2}\right)$ under different pastures. Values not sharing a common letter differ significantly $(P<0.05)$.

\begin{tabular}{lccc}
\hline & White clover & Lotus & Ryegrass \\
\hline May & $601 \mathrm{a}$ & $309 \mathrm{~b}$ & $14 \mathrm{c}$ \\
December & $332 \mathrm{~d}$ & $109 \mathrm{e}$ & $69 \mathrm{f}$ \\
\hline
\end{tabular}

Table 3 Numbers (per $\left.\mathrm{m}^{2}\right)$ and biomass $\left(\mathrm{g} / \mathrm{m}^{2}\right)$ of two earthworm species under different pastures in May. Values are the means of three replicates.

\begin{tabular}{lrrrr}
\hline & $\begin{array}{c}\text { Aporrectodea caliginosa } \\
\text { No. } / \mathrm{m}^{2}\end{array}$ & $\mathrm{~g} / \mathrm{m}^{2}$ & \multicolumn{2}{c}{$\begin{array}{c}\text { Lumbricus rubellus } \\
\text { No. } / \mathrm{m}^{2}\end{array}$} \\
$\mathrm{~g} / \mathrm{m}^{2}$
\end{tabular}


Figure 1 Nitrification rate ( $\mu \mathrm{N} \mathrm{NO}_{3}{ }^{-}-\mathrm{N} / \mathrm{g}$ dry soil) for four soils mixed with Lotus or white clover herbage.

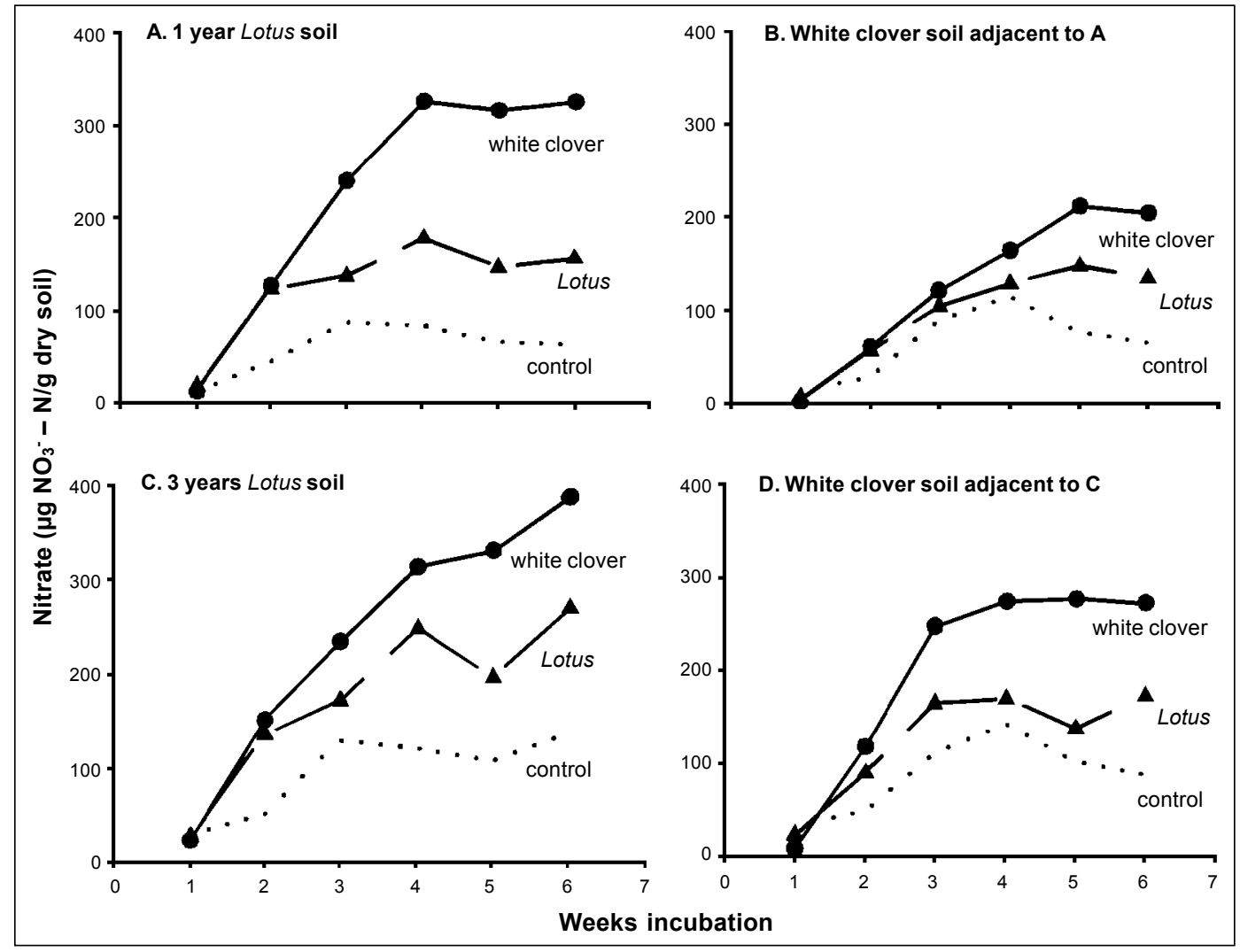

\section{Rate of dung disappearance}

The mean removal rate of dung (as a $\%$ of the initial amount present) by earthworms, in the sand cultures, for 2 experiments was $5 \%$ for white clover dung, $23 \%$ for ryegrass dung, and $65 \%$ for Lotus dung.

In the field plots, dung derived from ryegrass/Lotus herbage disappeared much faster (difference significant $P<0.001)$ than dung derived from ryegrass/clover pastures (Table 4). There was no difference in disappearance rate between the plus $\mathrm{N}$ and minus $\mathrm{N}$ fertiliser pasture dungs. All the dung residues showed an increase in $\% \mathrm{~N}$ in DM, and this was statistically significant for the plus $\mathrm{N}$ fertiliser pasture dung $(P<0.01)$, and the minus $\mathrm{N}$ fertiliser pasture dung $(P<0.001)$, but not for the dung derived from Lotus pasture.

\section{Discussion}

Tannins in forage plants have the potential to influence nutrient cycling at several levels in the soil-plant-animal system. Ruminants eating forage containing tannins excrete about $20 \%$ more of their surplus dietary $\mathrm{N}$ in
Table 4 Percentage of dung DM remaining on the soil surface after 11 weeks, and initial, and final $\mathrm{N}$ content of the dung.

\begin{tabular}{lccc}
\hline & $\begin{array}{c}\text { \% dung DM } \\
\text { remaining }\end{array}$ & $\begin{array}{c}\text { Initial \% N } \\
\text { in DM }\end{array}$ & $\begin{array}{c}\text { Final \% N } \\
\text { in DM }\end{array}$ \\
\hline Plus N pasture & 75.5 & 3.21 & 3.55 \\
Minus N pasture & 79.3 & 2.72 & 3.52 \\
Lotus pasture & 43.2 & 2.75 & 2.88 \\
\hline
\end{tabular}

dung and correspondingly less $\mathrm{N}$ in urine (Waghorn et al. 1994). This is important because urine patches are the dominant source of the $\mathrm{N}$ leached from grazed pastures (Ryden et al. 1984). We observed accelerated rates of incorporation of dung derived from Lotus in both laboratory and field experiments. This rapid incorporation has the potential to maintain the $\mathrm{N}$ supply for pasture growth. and to some extent compensate for a reduction in the $\mathrm{N}$ input into urine patches where animals are grazing tannin-rich pastures.

The experiment with clover and Lotus herbage incubated in soils of different crop histories demonstrated lower rates of accumulation of nitrate-N in the Lotus 
treatments. This confirms, for temperate forage species, earlier work with other tannin-containing species of mainly tropical origin.

The most important result from the incubation experiment was the evidence for an increase in nitrification rate in soil mixed with Lotus when the soil was collected from a 3-year-old Lotus stand compared with soil from a 1-year-old stand. This suggests that given sufficient exposure to tannin-containing residues, the soil microbial population changes and species or strains better able to decompose such residues become more active. When herbage and dung were incubated in a hill soil that had contained Lotus in the sward for some years, higher nitrification rates were indicated in the Lotus treatments. This occurred whether direct extraction of nitrate, or plant growth under $\mathrm{N}$-limiting conditions was used as the assay. These results confirm that the inhibitory effects of tannins in forages on nitrification, observed in the first experiment and reported in the literature, may not be universal and are influenced by the history of the experimental soils used. Further support for progressive adaptation of the soil microbial population to break down tannin-containing residues can be found in Brock (1973) who measured N uptake by ryegrass over 2 years in plots that had been in white clover or Lotus for the preceding 3 years. Similar amounts of $\mathrm{N}$ were harvested from former white clover and Lotus plots over the 2 years, but yields were higher from white clover in year 1 and from Lotus in year 2. It was suggested that differences in root quality might explain the delayed release of $\mathrm{N}$ in the Lotus plots. Changes in the soil microbial population towards types better able to decompose Lotus residues is another explanation of these results.

Earthworms are generally regarded as having beneficial effects in pasture soils. Different species have different behaviour but many contribute positively to nutrient cycling processes by increasing the rate of incorporation of plant residues and dung. The earthworm surveys show differences in earthworm biomass for clover, Lotus, and ryegrass crops. Densities of $A$. caliginosa and $L$. rubellus were markedly higher under the legume than under the ryegrass pastures and, furthermore, numbers were also higher under clover than under Lotus. These differences could arise from variation in several factors, singly or in combination, e.g., differences in crop growth and senescence rates, differences in the physical or chemical characteristics of crop residues, and differences in both temperature and soil moisture prevailing beneath the pasture canopies.

Differences in the rates of disappearance of the dung derived from the three pasture species, recorded in both laboratory and field trials, were not anticipated and highlight major differences in earthworm feeding preferences. An obvious implication is that because dung in Lotus pasture may be removed from the soil surface at a much higher rate than may occur in the other pastures, then differences in rates of nutrient turnover from dung can also be expected. Further information is needed to help define the roles of the different earthworm species in nutrient cycling in pastures dominated by different plant species.

There was a very strong trend of increase in $\mathrm{N}$ content of dung over 11 weeks on the surface of a pasture soil. This increase possibly resulted from colonisation of the dung by soil invertebrates and microfauna that would have higher protein contents than the digested herbage forming the fresh dung pat. Soil micro-organisms may also have preferentially removed carbon from the dung, leading to concentration of $\mathrm{N}$ in the dung residues.

\section{ACKNOWLEDGEMENTS}

James Evans, Matthew Mills, Li Ouyang, and Michelle Scott for technical support.

\section{REFERENCES}

Boothroyd, I.K.G.; Crush, J.R.; Ledgard, S.F.; Selvarajah, N. 1999. Impact of nitrogen flows from agricultural production environments on biodiversity of non-agricultural ecosystems in the Waikato Region, New Zealand. (In press). In: Mitchell, N.D.; Craig, J.L.; Saunders, D.A. (eds) Nature Conservation 5: Nature Conservation in a Production Environment. Surrey Beatty, Chipping Norton.

Brock, J.L. 1973. Growth and nitrogen fixation of pure stands of three pasture legumes with high/low phosphate. New Zealand journal of agricultural research 16: 483-491.

Eno, C.F. 1960. Nitrate production in the field by incubating the soil in polyethylene bags. Soil Science Society of America proceedings 24: 277-279.

Kholdebarin, B.; Oertli, J.J. 1994. Nitrification: Interference by phenolic compounds, Journal of plant nutrition 17: 1827-1837.

Lambert, M.G.; Clark, D.A.; Grant, D.A.; Costall, D.A. 1986. Influence of fertiliser and grazing management on North Island moist hill country. 2. Pasture botanical composition. New Zealand journal of agricultural research 29: 1-10.

Middleton, K.R.; Toxopeus, M.R.J. 1973. Diagnosis and measurement of multiple soil deficiencies by a subtractive technique. Plant and soil 38: 219-226.

Palm, C.A.; Sanchez, P.A. 1991. Nitrogen release from the leaves of some tropical legumes as affected by 
their lignin and polyphenolic contents. Soil biology and biochemistry 23: 83-88.

Ryden, J.C.; Ball. P.R.; Garwood, E.A. 1984. Nitrate leaching from grassland. Nature 311: 50-53.

Vallis, I.; Jones, R.J. 1973. Net mineralisation of nitrogen in leaves and leaf litter of Desmodium intortum and Phaseolus atropurpureus mixed with soil. Soil biology and biochemistry 5: 391-398.

Waghorn, G.C.; Shelton, I.D.; McNabb, W.C.; McCutcheon, S.N. 1994. Effects of condensed tannins in Lotus pedunculatus on its nutritive value for sheep. 2. Nitrogenous aspects. Journal of Agricultural Science (Cambridge) 123: 109-120. 